JoIE: Journal of Islamic Economics | Nur Afriyanti, Luhur Prasetiyo

\title{
Pengaruh Inflasi dan Pertumbuhan Ekonomi Terhadap Nilai Tukar Rupiah dalam Jangka Pendek dan Jangka Panjang Tahun 2010-2018
}

\section{Nur Afriyanti, Luhur Prasetiyo}

Fakultas Ekonomi dan Bisnis Islam Institut Agama Islam Negeri Ponorogo, Indonesia zahraafri88@gmail.com, luhur@iainponorogo.ac.id

\begin{abstract}
Abstrak: Artikel ini bertujuan untuk mengetahui pengaruh inflasi dan pertumbuhan ekonomi terhadap nilai tukar Rupiah, baik jangka panjang maupun jangka pendek. Perubahan nilai tukar Rupiah terhadap mata uang Dollar Amerika Serikat dipengaruhi oleh banyak faktor. Di antara faktor yang mempengaruhi nilai tukar adalah kenaikan harga umum (inflasi) dan pertumbuhan ekonomi. Penelitian ini menggunakan metode analisis data Error Correction Model (ECM) dan teknik pemilihan sampel menggunakan sampel jenuh dari populasi yang berjumlah 36. Sampel dalam penelitian ini yaitu data time series/triwulan inflasi, pertumbuhan ekonomi dan nilai tukar dengan periode pengamatan selama 9 tahun yaitu tahun 2010-2018. Hasil penelitian menunjukkan bahwa dalam jangka panjang nilai tukar dipengaruhi oleh inflasi dan pertumbuhan ekonomi. Sedangkan dalam jangka pendek nilai tukar tidak dipengaruhi oleh variabel inflasi dan pertumbuhan ekonomi. Secara bersama-sama variabel inflasi dan pertumbuhan ekonomi berpengaruh signifikan terhadap variabel nilai tukar.
\end{abstract}

Kata Kunci: Inflasi, pertumbuhan ekonomi, nilai tukar rupiah

Abstract: The purpose of this research is to determine the effect of inflation dan economic growth on Rupiah exchange rate, both long-term and short-term. The movement of Rupiah exchange rate to US Dollar is influenced by many factors. Among the factors affecting the exchange rate are general price increases (inflation) and economic growth. This research uses Error Correction Model (ECM) for data analysis. The population in this study amounted to 36 . The sample selection technique is saturated sample. The sample in this research is time series data on quarterly inflation, economic growth and the exchange rate in the period of 9 years, namely 2010-2018. The results show that in the long-term the exchange rate is influenced by inflation and economic growth. Whereas in the short-term the exchange rate is not influenced by inflation and economic growth variables. Furthermore, inflation and economic growth variables have a significant effect on the exchange rate variable.

Keywords: Inflation, growth economic, value of money

\section{PENDAHULUAN}

Globalisasi dalam bidang ekonomi menyebabkan berkembangnya sistem perekonomian ke arah perekonomian terbuka antar negara. Perkembangan ekonomi internasional yang semakin pesat dapat memacu perubahan indikator makro suatu negara. Perkembangan ini menyebabkan adanya perdagangan internasional. Perdagangan 
internasional memberikan keuntungan bagi negara, karena negara bisa menjual barangbarangnya ke luar negeri. Hal ini tentu saja dapat meningkatkan kekayaan dan kesejahteraan penduduknya. Motivasi hubungan dagang internasional tidak lain adalah sebagai upaya menciptakan efisiensi dalam pengalokasian sumber daya ekonomi antar negara dalam rangka meningkatkan utilitas sumber daya dunia untuk mencapai kemakmuran setiap bangsa dan negara.

Ada beberapa keuntungan dalam melakukan perdagangan luar negeri, yaitu memperoleh barang yang tidak dapat diproduksi di dalam negeri, memperoleh keuntungan dari spesialiasasi, dan memperluas pasar industri-industri dalam negeri (Sukirno, 2004, p. 360). Di dalam perdagangan internasional terdapat perbedaan mata uang yang digunakan untuk melakukan transaksi. Perbedaan mata uang ini merupakan salah satu indikator makro ekonomi. Maka dari itu diperlukan adanya mata uang yang sama sehingga mata uang kedua negara dapat dikonversikan ke dalam mata uang lain dengan menggunakan satuan ukuran nilai tukar mata uang yang disebut kurs. Kurs valuta asing atau kurs mata uang asing menunjukkan harga atau nilai mata uang sesuatu negara dinyatakan dalam nilai mata uang negara lain atau dapat didefinisikan sebagai jumlah uang domestik yang dibutuhkan, yaitu banyaknya rupiah yang dibutuhkan, untuk memperoleh satu unit mata uang asing (Sukirno, 2004, p. 397).

Perubahan nilai tukar akan berpengaruh terhadap perekonomian dan kehidupan kita sehari-hari, karena jika Dollar AS mengalami apresiasi terhadap mata uang rupiah. Barang-barang di Indonesia menjadi relatif murah untuk orang-orang Amerika dan barangbarang Amerika relatif mahal bagi orang-orang Indonesia. Jika terjadi sebaliknya, jika Dollar AS mengalami depresiasi terhadap rupiah, maka barang-barang Indonesia menjadi lebih mahal bagi orang-orang Amerika dan barang-barang Amerika menjadi lebih murah bagi orang-orang Indonesia (Natsir, 2014, p. 303).

Perubahan nilai tukar Rupiah terhadap mata uang Dollar Amerika Serikat dipengaruhi oleh banyak faktor. Salah satunya adalah kondisi makro ekonomi suatu negara. Ada beberapa faktor yang mempengaruhi kurs yaitu : perubahan dalam citarasa masyarakat, perubahan harga barang ekspor dan impor, kenaikan harga umum (inflasi), perubahan suku bunga dan tingkat pengembalian investasi, dan pertumbuhan ekonomi (Sukirno, 2004, pp. 402-403). Kondisi makro ekonomi yang digunakan sebagai variabel bebas dalam mempengaruhi perubahan nilai tukar rupiah adalah tingkat inflasi dan pertumbuhan ekonomi. 
Inflasi adalah suatu keadaan dimana terdapat kenaikan harga umum secara terusmenerus. Jadi, bukan kenaikan harga satu atau dua macam barang saja, melainkan kenaikan harga dari sebagian besar barang dan jasa, dan pula bukan hanya satu atau dua kali kenaikan harga, melainkan kenaikan harga secara terus menerus (Suparmoko, 1994, p. 187). Menurut Sukirno (2004, p. 402), inflasi sangat besar pengaruhnya kepada kurs pertukaran valuta asing. Inflasi yang berlaku pada umumnya cenderung untuk menurunkan nilai sesuai valuta asing.

Selain itu, kondisi lain yang dapat menyebabkan perubahan nilai tukar rupiah juga dipengaruhi oleh pertumbuhan ekonomi. pertumbuhan ekonomi adalah suatu kondisi dimana terjadinya perkembangan GNP yang mencerminkan adanya pertumbuhan output per kapita dan meningkatnya standar hidup masyarakat (Murni, 2013, p. 171). Kemajuan ekonomi akan memberikan efek kepada nilai mata uangnya tergantung kepada corak pertumbuhan ekonomi yang berlaku.

\section{TINJAUAN LITERATUR}

\section{Inflasi}

Inflasi merupakan salah satu dari sekian masalah ekonomi yang cukup banyak mendapat perhatian para ekonom. Sebagaimana diketahui, bahwa salah satu tujuan utama dalam perekonomian yaitu memelihara tingkat harga-harga yang relatif stabil. Menurut Rahardja dan Manurung (2008, p. 165), inflasi adalah kenaikan harga barang-barang yang bersifat umum dan terus-menerus. Dari definisi ini, ada tiga komponen yang harus dipenuhi agar dapat dikatakan telah terjadi inflasi, yaitu kenaikan harga, bersifat umum dan berlangsung terus-menerus. Indikator yang sering digunakan untuk mengukur tingkat inflasi adalah Indeks Harga Konsumen (IHK).

\section{Pertumbuhan Ekonomi}

Pertumbuhan ekonomi merupakan kejadian ekonomi yang bersifat jangka panjang dan merupakan sumber utama dalam peningkatan standar hidup ekonomi masyarakat. Istilah pertumbuhan ekonomi digunakan untuk menggambarkan terjadinya kemajuan atau perkembangan ekonomi dalam suatu negara. Suatu negara kadang mengalami pertumbuhan ekonomi yang lambat dan kadang juga mengalami pertumbuhan yang pesat. Suatu perekonomian dikatakan mengalami pertumbuhan, jika jumlah produk barang dan jasanya meningkat atau dengan kata lain terjadi peningkatan GNP pada suatu negara. Pertumbuhan ekonomi harus mencerminkan output per kapita. Dengan pertumbuhan perkapita, berarti terjadi pertumbuhan upah riil dan meningkatnya standar hidup. Dari 
JoIE: Journal of Islamic Economics | Nur Afriyanti, Luhur Prasetiyo

penjelasan di atas dapat disimpulkan mengenai definisi pertumbuhan ekonomi yaitu pertumbuhan ekonomi adalah suatu kondisi di mana terjadinya perkembangan GNP yang mencerminkan adanya pertumbuhan output per kapita dan meningkatnya standar hidup masyarakat (Murni, 2013, p. 171).

\section{Nilai Tukar}

Menurut M. Natsir, nilai tukar adalah harga dari suatu mata uang dalam mata uang negara lain, misalnya nilai rupiah setelah dikonversi dalam dolar AS. Miskhin menyatakan bahwa "exchange rate is the price of one currency in terms of another" (nilai tukar adalah harga satu mata uang dakam hal yang lain). Selanjutnya Van Hoose \& Miller sebagaimana dikutip oleh Murni menyatakan bahwa "exchange rate is the price of one nation currency in terms of the currency of the another country" (nilai tukar adalah harga mata uang suatu negara dalam hal mata uang negara lain) (Murni, 2013). Sedangkan menurut Mankiw (2007), kurs (exchange rate) antara dua negara adalah tingkat harga yang disepakati penduduk kedua negara untuk saling melakukan perdagangan.

Menurut Sukirno (2004), perubahan dalam kurs valuta asing dapat disebabkan oleh beberapa faktor yaitu perubahan dalam citarasa masyarakat, perubahan harga barang ekspor dan impor, kenaikan harga umum (inflasi), perubahan suku bunga dan tingkat pengembalian investasi, dan pertumbuhan ekonomi.

\section{Inflasi dan Nilai Tukar}

Inflasi erat kaitanya dengan nilai tukar mata uang, perubahan tingkat inflasi dapat mempengaruhi permintaan mata uang di suatu negara, sehingga dapat pula mempengaruhi pola perdagangan internasional. Menurut Jeff Madura (2006), perubahan tingkat inflasi relatif dapat mempengaruhi aktivitas perdagangan internasional, yang akan mempengaruhi permintaan dan penawaran suatu mata uang dan karenanya mempengaruhi kurs nilai tukar. Perubahan nilai tukar yang berubah ubah setiap saat ini dapat menyebabkan terjadinya depresiasi dan apresiasi terhadap mata uang itu sendiri. Apresiasi merupakan peningkatan suatu mata uang sedangkan depresiasi adalah penurunan nilai pada suatu mata uang. Tingkat inflasi antar negara berbeda, sehingga pola perdagangan internasional dan nilai tukar akan berubah sesuai dengan inflasi tersebut.

Teori paritas daya beli (purchasing power parity) menyatakan bahwa satu unit mata uang tertentu harus mampu membeli barang dalam jumlah yang sama di semua negara (Sudarmiani, 2017, p. 34). Inflasi yang tinggi cenderung akan menurunkan nilai mata uang dari suatu negara. Sebaliknya nilai mata uang suatu negara yang mempunyai 
inflasi rendah akan mengalami apresiasi. Hal ini merupakan alasan mengapa tingkat inflasi menjadi bagian yang turut diperhatikan oleh para pelaku perdagangan mata uang asing.

\section{Pertumbuhan Ekonomi dan Nilai Tukar}

Pertumbuhan ekonomi merupakan kejadian ekonomi yang bersifat jangka panjang dan merupakan sumber utama dalam peningkatan standar hidup ekonomi masyarakat. Menurut Sukirno (2004), pertumbuhan ekonomi yang lesu memungkinkan kondisi ekonomi yang tidak stabil dan situasi politik yang tidak kondusif akibatnya kegiatankegiatan ekonomi menjadi menurun termasuk kegiatan produksi maupun investasi. Kondisi ekonomi suatu negara yang tidak stabil akan mempengaruhi nilai tukar negara tersebut.

Kemajuan ekonomi akan memberikan efek kepada nilai tukar mata uang suatu negara tersebut sesuai dengan pertumbuhan ekonomi yang berlaku. Kemajuan ekonomi terutama diakibatkan oleh ekspor, maka permintaan mata uang suatu negara akan lebih cepat bertambah. Selain itu, apabila kemajuan ekonomi menyebabkan impor berkembang lebih cepat dari ekspor, maka penawaran mata uang suatu negara akan lebih cepat bertambah dari permintaannya, oleh karena itu nilai mata uang suatu negara akan merosot atau melemah.

\section{Inflasi dan Pertumbuhan Ekonomi terhadap Nilai Tukar Rupiah}

Perubahan nilai tukar rupiah dipengaruhi oleh beberapa faktor salah satunya yaitu inflasi dan pertumbuhan ekonomi. Inflasi sangat besar pengaruhnya terhadap nilai tukar rupiah. Apabila inflasi menyebabkan harga-harga di dalam negeri lebih mahal dari harga-harga di luar negeri dan oleh sebab itu inflasi berkecenderungan menambah impor sehingga permintaan atas mata uang suatu negara akan bertambah. Selain itu, apabila inflasi menyebabkan harga ekspor lebih mahal, maka inflasi berkecenderungan mengurangi ekspor sehingga penawaran mata uang suatu negara akan berkurang (Sukirno, 2004, p. 402).

\section{METODE PENELITIAN}

\section{Jenis Penelitian}

Jenis penelitian yang digunakan dalam penelitian ini adalah penelitian kuantitatif, yakni penelitian yang dibangun berdasarkan filsafat positivisme. Positivisme adalah satu aliran filsafat yang menolak unsur metafisik dan teologik dari realitas sosial (Herlambang, 2019). Filsafat positivisme digunakan untuk meneliti pada populasi atau sampel tertentu, 
pengumpulam data menggunakan instrumen penelitian, analisis data bersifat statistik dengan tujuan untuk menguji hipotesis yang telah ditetapkan. Penelitian ini menggunakan angka-angka yang dijumlahkan sebagai data yang kemudian dianalisis. Metode ini dimaksud untuk menjelaskan fenomena dengan menggunakan data-data numerik, serta time series kemudian dianalisis yang umumnya menggunakan statistik.

\section{Lokasi Penelitian}

Penelitian ini dilakukan pada Bank Indonesia sebagai Bank Sentral dan Badan Pusat Statistika (BPS). Data yang diperoleh langsung dari media perantara yaitu situs resmi Badan Pusat Statistika (www.bps.go.id) dan situs resmi Bank Indonesia (www.bi.go.id) yang mendukung untuk data penelitian.

\section{Populasi}

Populasi adalah keseluruhan elemen yang akan dijadikan wilayah generalisasi. Elemen populasi adalah keseluruhan subyek yang akan diukur, yang merupakan unit yang diteliti (Sugiyono, 2018, p. 130). Populasi juga bukan sekedar jumlah yang ada pada obyek/subyek yang dipelajari, tetapi meliputi seluruh karakteristik/sifat yang dimiliki oleh subyek atau obyek itu. Populasi dalam penelitian ini adalah inflasi, pertumbuhan ekonomi dan nilai tukar rupiah.

\section{Sampel}

Sampel adalah bagian dari jumlah dan karakteristik yang dimiliki oleh populasi tersebut. Sampel data dalam penelitian ini diambil dengan teknik sampling jenuh. Sampling jenuh adalah teknik penentuan sampel bila semua anggota populasi digunakan sebagai sampel. Istilah lain sampel jenuh adalah sensus, dimana semua anggota populasi dijadikan sampel (Sugiyono, 2012, p. 85). Sampel dalam penelitian ini yaitu adalah data time series/triwulan inflasi, pertumbuhan ekonomi dan nilai tukar dengan periode pengamatan selama 9 tahun yaitu tahun 2010-2018.

\section{Variabel Penelitian}

Variabel penelitian adalah suatu atribut atau sifat atau nilai dari orang, obyek atau kegiatan yang mempunyai variasi tertentu yang ditetapkan oleh peneliti untuk dipelajari dan kemudian ditarik kesimpulannya. Variabel yang digunakan dalam penelitian ini secara garis besar dibagi menjadi dua, yaitu variabel independent dan variabel dependent.

Variabel bebas (independent) dalam penelitian ini adalah :

1. Inflasi adalah kecenderungan naiknya harga barang dan jasa pada umumnya yang berlangsung secara terus menerus. Jika harga barang dan jasa di dalam negeri 
meningkat, maka inflasi mengalami kenaikan. Naiknya harga barang dan jasa tersebut menyebabkan turunnya nilai uang. Dengan demikian, inflasi dapat juga diartikan sebagai penurunan nilai uang terhadap nilai barang dan jasa secara umum (Rahardja $\&$ Manurung, 2008, p. 155).

2. Kedua pertumbuhan ekonomi (X2), pertumbuhan merupakan sebuah kata benda yang berkaca dasar ‘tumbuh'. Tumbuh menurut Kamus Besar Bahasa Indonesia (KBBI) berarti timbul, bertambah besar atau sempurna. Sementara pertumbuhan berarti hal (keadaan) tumbuh, perkembangan (kemajuan dan sebagainya). Pertumbuhan ekonomi dapat berarti kenaikan produk nasional bruto di suatu negara (Beik \& Arsyianti, 2017, p. 20).

Variabel terikat (dependent) dalam penelitian ini adalah Nilai tukar atau kurs adalah harga mata uang suatu negara terhadap negara lain atau mata uang suatu negara dinyatakan dalam mata uang negara lain. Suatu kenaikan dalam kurs disebut depresiasi atau penurunan nilai mata uang dalam negeri terhadap mata uang asing. Suatu penurunan dalam kurs disebut apresiasi, atau kenaikan dalam nilai mata uang dalam negeri. Pada umumnya, kurs ditentukan oleh perpotongan kurva permintaan pasar dan kurva penawaran dari mata uang asing tersebut (Bato, Taufiq, \& Putri, 2017, p. 81).

\section{Teknik Pengumpulan Data}

Teknik pengumpulan data yang digunakan dalam penelitian ini adalah dengan dokumen. Dokumen merupakan catatan peristiwa yang sudah berlalu. Dokumen bisa berbentuk tulisan, gambar, atau karya-karya monumental dari seseorang. Dokumen yang berbentuk tulisan misalnya catatan harian, sejarah kehidupan (life histories), cerita, biografi, peraturan, kebijakan (Sugiyono, 2012, p. 240) Ketika menggunakan metode ini sebagai metode pengumpulan data, maka peneliti bisa menggunakan data yang ada dengan hanya membuat salinan atau menggandakanya.

\section{Teknik Analisis Data}

Menurut Widarjono (2009, p. 315)' data time series seringkali tidak stasioner sehingga menyebabkan hasil regresi meragukan atau disebt regresi lancing. Para ahli ekonometrika mengembangkan beberapa metode analisis yang difokuskan dalam ekonometrika time series dan dari pengembangan tersebut didapatkan suatu model yang tepat untuk menangani masalah terjadinya regresi lancung, yakni Error Correction Model (ECM). Sehingga metode penelitian yang digunakan dalam penelitian ini adalah Error Correction Model (ECM). 
JoIE: Journal of Islamic Economics | Nur Afriyanti, Luhur Prasetiyo

\section{Uji Stasioneritas}

Tujuan uji stasioner ini adalah agar mean-nya stabil dan random error $=$ nol, sehingga model regresi yang diperoleh mempunyai kemampuan prediksi yang andal dan tidak spurious.Pengujian untuk mengukur stasioneritas data dilakukan dengan menggunakan Augmented Dickey Fuler (ADF) test dan uji akar-akar unit (unit root test).

2. Uji Kointegrasi

Uji kointegrasi merupakan salah satu metode untuk mengindikasikan kemungkinan adanya hubungan kesetimbangan (equilibrium) jangka panjang antara variabel dependen dan variabel independen. Namun, walaupun terdapat kesetimbangan jangka panjang akan tetapi dalam jangka pendek mungkin saja keduanya tidak mencapai kesetimbangan (Muhammad, 2014, p. 41).

3. Uji Asumsi Klasik

Uji asumsi klasik digunakan model statistik parametrik sehingga sebelum analisis data terlebih dahulu diperlukan uji asumsi klasik bertujuan untuk mendapatkan estimasi. Uji asumsi tersebut meliputi normalitas, heteroskedastisitas, autokorelasi, dan linieritas.

a. Normalitas

Uji normalitas bertujuan untuk menguji apakah dalam model regresi, variabel pengganggu atau residual mempunyai distribusi normal. Ada dua cara mendeteksi apakah residual memiliki distribusi normal atau tidak, yaitu dengan analisis grafik dan uji statistik.

b. Heteroskedastisitas

Salah satu asumsi yang penting dari regresi linier klasik adalah varian residual bersifat homoskedastisitas atau konstan. Apabila asumsi tersebut tidak terpenuhi maka varian residual tidak lagi bersifat konstan atau yang disebut dengan heteroskedastisitas.

c. Autokorelasi

Masalah autokorelasi merujuk pada hubungan error term antar dua pengamatan. Autokorelasi terjadi pada serangkaian data runtut waktu, dimana error term pada satu periode waktu secara sistematik tergantung pada error term pada periodeperiode waktu yang lain.

d. Multikolinieritas 
JoIE: Journal of Islamic Economics | Nur Afriyanti, Luhur Prasetiyo

Uji multikolinieritas bertujuan untuk menguji apakah dalam model regresi ditemukan adanya korelasi yang tinggi atau sempurna antar variabel independen. Jika antar variabel independen terjadi multikolinieritas sempurna, maka koefisien regresi variabel independen tidak dapat ditentukan dan nilai standard error menjadi tak terhingga. Jika multikolinieritas antar variabel tinggi, maka koefisien regresi variabel independen dapat ditentukan, tetapi memiliki nilai standard error tinggi berarti nilai koefisien regresi tidak dapat diestimasi dengan tepat (Janie, 2012, p. 19).

\section{HASIL DAN PEMBAHASAN}

\section{Hasil Uji Stasioneritas}

Uji kestasioneran dalam model penelitian ini didasarkan pada uji Augmented Dickey Fuller (ADF) pada tingkat level, first difference, dan second difference. Dari tabel 1. dapat diketahui bahwasanya semua variabel sudah stasioner pada tingkat second difference yang dapat dilihat dari nilai probabilitas ADF menunjukkan angka kurang dari 0.05. Hasil juga menunjukkan bahwa nilai t-statistik > nilai kritis MacKinnon pada level 1\% sebesar -3.64 , level 5\% sebesar -2.95 , dan level 10\% sebesar -2.61 , sehingga dapat dikatakan bahwa pengujian ini menolak $\mathrm{H}_{0}$ yang artinya data telah stasioner.

Tabel 1. Hasil Uji Augmented Dickey Fuller Pada Second Difference

\begin{tabular}{lcc}
\hline \multicolumn{1}{c}{ Variabel } & \multicolumn{2}{c}{ ADF } \\
\cline { 2 - 3 } & t-Statistik & Prob. \\
\hline Nilai Tukar & $-7.006201^{* * *}$ & 0.0000 \\
\hline Inflasi & $-6.739750^{* * *}$ & 0.0000 \\
\hline PDB & $-101.9675^{* * *}$ & 0.0001 \\
\hline Test Critical Values (MacKinnon) & \\
\hline $\mathbf{1 \%}$ Level & -3.646342 \\
\hline $\mathbf{5 \%}$ Level & -2.954021 \\
\hline $\mathbf{1 0 \%}$ Level & -2.615817 \\
\hline
\end{tabular}

Sumber: Hasil pengolahan eviews 9.0 
JoIE: Journal of Islamic Economics | Nur Afriyanti, Luhur Prasetiyo

Dari tabel 1. dapat diketahui bahwasanya semua variabel sudah stasioner pada tingkat second difference yang dapat dilihat dari nilai probabilitas ADF menunjukkan angka kurang dari 0.05 . Hasil juga menunjukkan bahwa nilai t-statistik $>$ nilai kritis MacKinnon pada level 1\% sebesar -3.64, level 5\% sebesar -2.95, dan level 10\% sebesar 2.61, sehingga dapat dikatakan bahwa pengujian ini menolak $\mathrm{H}_{0}$ yang artinya data telah stasioner.

\section{Hasil Uji Kointegrasi}

\section{Tabel 2. Hasil Uji Kointegrasi Tingkat Level}

Nilai Tukar

t-Statistik Prob.

\begin{tabular}{lcc}
\hline $\begin{array}{l}\text { Augmented Dickey-Fuller test } \\
\text { statistic }\end{array}$ & $-3.515296^{*}$ & 0.0134 \\
\hline Test critical values: & $1 \%$ level & -3.632900 \\
\hline & $5 \%$ level & -2.948404 \\
\hline & $10 \%$ level & -2.612874
\end{tabular}

Sumber: Hasil pengolahan eviews 9.0

Dari Tabel 2. dapat diketahu bahwa nilai tukar memiliki hubungan kointegrasi. Hal itu dapat dilihat dari probabilitas unit root test pada Augmented Dickey-Fuller test statistic yang menunjukkan bahwa residual telah stasioner pada tingkat level dengan probabilitas $<0.05$ atau nilai t-statistik ADF test $>$ nilai kritis MacKinnon pada level 5\%. Oleh karena itu, dapat diartikan bahwa pada pengujian ini menolak $\mathrm{H}_{0}$ atau terdapat hubungan kointegrasi pada semua model yang diajukan.

\section{Hasil Uji Model Jangka Panjang}

Tabel 3. Hasil Uji Jangka Panjang 
JoIE: Journal of Islamic Economics | Nur Afriyanti, Luhur Prasetiyo

\begin{tabular}{lccc}
\hline Variabel & \multicolumn{3}{c}{ Nilai Tukar } \\
& Coeff. & t-Stat. & Prob. \\
\cline { 2 - 4 } & & & \\
\hline INF & 0.015973 & 2.379474 & 0.0233 \\
\hline LOG(PDB) & 1.335991 & 16.31940 & 0.0000 \\
\hline $\begin{array}{l}\text { Prob. F- } \\
\text { Statistik }\end{array}$ & & 0.000000 \\
\hline $\begin{array}{l}\text { Adjusted } \\
\mathbf{R}^{2}\end{array}$ & & \\
\hline
\end{tabular}

Sumber: Hasil pengolahan eviews 9.0

Dari Tabel 3 dapat diketahui nilai probabilitas F-statistik pada variabel niali tukar kurang dari 0.05, maka dapat dikatakan bahwa variabel inflasi dan PDB secara bersamasama berpengaruh signifikan terhadap variabel nilai tukar dalam model jangka panjang.

Nilai Adjusted $\mathrm{R}^{2}$ variabel nilai tukar menunjukkan angka 0.889 , hal ini berarti sebesar $88.9 \%$ variabel dependen nilai tukar dapat dijelaskan oleh variabel independen inflasi dan PDB. Sedangkan sisanya, $(100 \%-88.9 \%=11.1 \%)$ dijelaskan oleh variabel lain di luar penelitian.

Dalam jangka panjang pada variabel inflasi memiliki pengaruh yang positif dan signifikan terhadap nilai tukar karena nilai probabilitas t-statistik $0,0233<0.05\left(\mathrm{H}_{0}\right.$ diterima). Sedangka PDB juga memiliki pengaruh yang positif dan signifikan terhadap nilai tukar karena nila probabilitas t-statistik $0,0000<0.05\left(\mathrm{H}_{0}\right.$ diterima).

\section{Hasil Uji Model Jangka Pendek}

Tabel 4. Hasil Uji Jangka Pendek

\begin{tabular}{|c|c|c|c|}
\hline \multirow[t]{2}{*}{ Variabel } & \multicolumn{3}{|c|}{ Nilai Tukar } \\
\hline & Coeff. & t-Stat. & Prob. \\
\hline D(INF) & & 1.956092 & 0.0595 \\
\hline D(LOG(PDB)) & 0.122465 & 0.684310 & 0.4989 \\
\hline \multirow[t]{2}{*}{ ECT(-1) } & - & - & 0.0010 \\
\hline & 0.262501 & 3.646049 & \\
\hline
\end{tabular}


JoIE: Journal of Islamic Economics | Nur Afriyanti, Luhur Prasetiyo

Prob. F-Statistik

0.002872

Adjusted R $\mathbf{R}^{2}$

0.297566

Sumber: Hasil pengolahan eviews 9.0

Dari Tabel 4.6 dapat diketahui bahwa variabel nilai tukar nilai probabilitas Fstatistik $<0.05$, maka dapat dikatakan bahwa variabel inflasi dan PDB secara bersama sama berpengaruh signifikan terhadap variabel nilai tukar dalam model jangka pendek.

Nilai Adjusted $\mathrm{R}^{2}$ menunjukkan angka 0.297, hal ini berarti sebesar 29.7\% variabel dependen nilai tukar dapat dijelaskan oleh variabel independen inflasi dan PDB. Sedangkan sisanya $(100 \%-29.7 \%=70.3 \%)$ dijelaskan oleh variabel lain di luar penelitian.

Dalam jangka pendek tidak ada yang berpengaruh terhadap nilai tukar, karena nilai probabilitas F-statistik $>0.05\left(\mathrm{H}_{0}\right.$ ditolak).

\section{Hasil Uji Asumsi Klasik}

\section{Uji Normalitas}

Berdasarkan uji normalitas dapat diketahui bahwa nilai probabilitas Jarque-Bera sebesar 2.563. Karena nilai probabilitas Jarque-Bare $>0.05$, maka dapat disimpulkan bahwa residual telah terdistribusi normal ( $\mathrm{H}_{0}$ diterima).

\section{Uji Heteroskedastisitas}

Dapat dilihat bahwa nilai probabilitas Chi-square yaitu lebih dari 0.05 untuk variabel nilai tukar, yang artinya bahwa pengujian tersebut menerima $\mathrm{H}_{0}$ atau tidak terdapat masalah heteroskedastisitas pada model ECM.

\section{Uji Autokorelasi}

Berdasarkan hasil pengujian, dapat diketahui bahwa probabilitas Chi-square yaitu lebih dari 0.05. maka dapat disimpulkan bahwa pengujian tersebut menerima $\mathrm{H}_{0}$ atau tidak terdapat masalah autokorelasi dalam variabel nilai tukar.

\section{Uji Multikolinieritas}


JoIE: Journal of Islamic Economics | Nur Afriyanti, Luhur Prasetiyo

Dapat diketahui bahwa nilai contered VIF pada variabel inflasi dan produk domestik bruto kurang dari 10, sehingga dapat dikatakan bahwa pada model nilai tukar tidak terdapat masalah multikolinieritas dalam model $\left(\mathrm{H}_{0}\right.$ diterima).

\section{Pengaruh Inflasi terhadap Nilai Tukar Rupiah}

Hasil penelitian menunjukkan bahwa variabel inflasi dalam jangka panjang berpengaruh positif dan signifikan terhadap nilai tukar rupiah (lihat Tabel 4.5), hasil tersebut juga sudah sesuai dengan hipotesis yang diajukan. Sesuai dengan penjelasan diatas dapat disimpulkan bahwa dalam jangka panjang inflasi berpengaruh positif dan signifikan terhadap nilai tukar rupiah. Hasil tersebut sesuai dengan teori yang dikemukakan oleh Mankiw dan Mishkin bahwa ketika mata uang sebuah negara mengalami apresiasi, barang negara tersebut harganya akan lebih mahal di luar negeri dan barang luar negeri tersebut harganya akan lebih murah dan begitupun sebaliknya. Selain itu hasil penelitian ini juga sejalan dengan penelitian sebelumnya yang dilakukan oleh Minkhatul Khajjah dan Roshita Puspitaningrum dengan hasil bahwa semakin tinggi tingkat inflasi di Indonesia maka akan mengakibatkan nilai tukar rupiah mengalami depresiasi terhadap Dollar AS. Pergerakan inflasi pada beberapa tahun terakhir mempengaruhi nilai tukar rupiah terhadap Dollar AS. Tingginya inflasi pada tahun 2013 disebabkan oleh naiknya harga bahan bakar minyak (BBM) yang diikuti naiknya harga seluruh kelompok pengeluaran seperti kelompok bahan makanan, rokok dan tembakau, air, listrik gas, dan lain-lainnya. Hal ini menyebabkan pertumbuhan ekonomi menurun sehingga daya beli masyarakat menurun. Ini dapat dilihat bahwa selama periode pengamatan tingkat inflasi mempengaruhi nilai tukar rupiah yang menyebabkan terdepresiasi karena inflasi sangat besar pengaruhnya kepada kurs pertukaran valuta asing.

Teori yang menerangkan hubungan antara nilai tukar dan inflasi diantara dua negara adalah teori paritas daya beli (purchasing power parity-PPP). Menurut Madura dalam jurnal Roshinta Puspitaningrum, dkk (2014) menyatakan bahwa keseimbangan kurs akan menyesuaikan dengan besaran perbedaan tingkat inflasi di antara dua negara. Hal ini akan berakibat daya beli konsumen untuk membeli produk-produk domestik akan sama dengan daya beli mereka untuk membeli produkproduk luar negeri.

Sedangkan dalam model jangka pendek inflasi tidak berpengaruh terhadap nilai tukar rupiah karena nilai probabilitas t-statistik $>0.05$ (0.0595.0.05) artinya $\mathrm{H}_{0}$ ditolak. Pergerakan inflasi pada beberapa tahun terakhir masih dalam kategori ringan karena inflasi 
JoIE: Journal of Islamic Economics | Nur Afriyanti, Luhur Prasetiyo

masih di bawah 10\% sehingga tidak terlalu mempengaruhi nilai tukar rupiah terhadap Dollar AS. Berdasarkan penelitian uji jangka pendek maka naik turunnya inflasi tidak mempengaruhi perubahan nilai tukar rupiah terhadap Dollar AS, karena inflasi relatif terkendali.

\section{Pengaruh Pertumbuhan Ekonomi terhadap Nilai Tukar Rupiah}

Dalam jangka panjang pertumbuhan ekonomi berpengaruh positif dan signifikan terhadap nilai tukar rupiah. Hasil tersebut sesuai dengan teori yang dikemukakan oleh Sadono Sukirno yaitu kemajuan ekonomi akan memberikan efek kepada nilai mata uangnya tergantung kepada corak pertumbuhan ekonomi yang berlaku. Apabila kemajuan itu terutama diakibatkan oleh perkembangan ekspor, maka permintaan ke atas mata uang negara itu bertambah lebih cepat dari penawarannya dan oleh karenanya nilai mata uang negara itu naik. Akan tetapi, apabila kemajuan tersebut menyebabkan impor berkembang lebih cepat dari ekspor, penawaran mata uang negara itu lebih cepat bertambah dari permintaannya dan oleh karenanya nilai mata uang negara tersebut akan merosot. Berbeda dengan penelitian yang dilakukan oleh peneliti sebelumnya dengan hasil bahwa secara parsial pertumbuhan ekonomi berpengaruh tetapi tidak signifikan.

Dapat dilihat bahwa pertumbuhan ekonomi dari tahun ke tahun mengalami naik turun. Pada triwulan terakhir 2014 ekonomi Indonesia menurun sehingga menarik turun pertumbuhan ekonomi pada tahun tersebut. Pada tahun 2014 merupakan pertumbuhan ekonomi yang terendah sejak 2009. Jika kondisi perekonomian suatu negara lesu yang mengakibatkan jumlah produksi dalam negeri menurun sehingga terjadi penurunan permintaan barang-barang domestik diluar negeri, maka permintaan atas mata uang domestik akan menurun oleh karenanya nilai tukar akan melemah.

Sedangkan dalam model jangka pendek pertumbuhan ekonomi tidak berpengaruh signifikan terhadap nilai tukar rupiah karena nilai probabilitas t-statistik $>0.05$ $(0.4989>0.05)$ artinya $\mathrm{H}_{0}$ diterima. Hal ini sesuai dengan hipotesis yang diajukan . Hubungan yang tidak signifikan ini disebabkan karena tingkat pertumbuhan ekonomi Indonesia yang relatif stabil dan masyarakat Indonesia cenderung memilih menggunakan barang dari luar negeri daripada barang domestik. Keadaan tersebut menyebabkan fundamental ekonomi yang kurang baik dan kemudian berdampak pula pada makroekonomi di Indonesia sehingga masyarakat Indonesia lebih memilih membeli barang daripada memegang uang. 


\section{Pengaruh Inflasi dan Pertumbuhan Ekonomi terhadap Nilai Tukar Rupiah}

Berdasarkan uji model jangka panjang dapat dilihat bahwa nilai probabilitas Fstatistik pada variabel niali tukar kurang dari $0.05(0.000000<0.05)$, dan nilai probabilitas t-statistik $<0.05\left(\mathrm{H}_{0}\right.$ diterima), secara bersama-sama variabel inflasi dan pertumbuhan ekonomi berpengaruh signifikan terhadap variabel nilai tukar. Maka dapat dikatakan bahwa variabel inflasi dan PDB secara bersama-sama berpengaruh signifikan terhadap variabel nilai tukar dalam model jangka panjang.

Perubahan dalam permintaan dan penawaran kurs valuta, yang selanjutnya menyebabkan perubahan dalam kurs valuta, disebabkan oleh banyak faktor, salah satunya yaitu inflasi dan pertumbuhan ekonomi. Jika kurs melemah maka harga-harga barang baku dan impor akan menjadi lebih mahal sehingga diperlukan rupiah yang lebih banyak guna untuk membeli bahan baku impor. Dengan melemahnya kurs akan mempengaruhi pola pembentukan harga produk oleh perusahaan yang dapat mendorong terjadinya inflasi. Begitu pula dengan pertumbuhan ekonomi, apabila kemajuan itu terutama diakibatkan oleh perkembangan ekspor, maka permintaan ke atas mata uang negara itu bertambah lebih cepat dari penawarannya dan oleh karenanya nilai mata uang negara itu naik. Akan tetapi, apabila kemajuan tersebut menyebabkan impor berkembang lebih cepat dari ekspor, penawaran mata uang negara itu lebih cepat bertambah dari permintaannya dan oleh karenanya nilai mata uang negara tersebut akan merosot.

Sedangkan pada uji jangka pendek pertumbuhan ekonomi dan inflasi tidak berpengaruh secar simultan terhadap nilai tukar rupiah, karena nilai probabilitas F-statistik $>0.05\left(\mathrm{H}_{0}\right.$ ditolak artinya tidak terdapat hubungan jangka pandek antara variable inflasi dan pertumbuhan ekonomi terhadap nilai tukar rupiah). Pergerakan inflasi pada beberapa tahun terakhir tidak terlalu mempengaruhi nilai tukar karena inflasi masih di bawah $10 \%$ sehingga dapat dikatakan bahwa inflasi masih dikategorikan sebagain inflasi ringan. Nilai tukar juga dipengaruhi corak keadaan perekonomian suatu negara, apabila keadaan ekonomi yang baik mengakibatkan peningkatan impor yang lebih besar sehingga terjadi defisit neraca perdangan maka keadaan tersebut bertendensi melemahkan nilai tukar.

\section{KESIMPULAN}

Berdasarkan hasil penelitian dan pembahasan mengenai pengaruh inflasi dan pertumbuhan ekonomi terhadap nilai tukar rupiah tahun 2010-2018 dapat disimpulkan 
JoIE: Journal of Islamic Economics | Nur Afriyanti, Luhur Prasetiyo

bahwa inflasi berpengaruh terhadap nilai tukar rupiah. Berdasarkan uji jangka panjang menunjukkan bahwa inflasi memiliki pengaruh yang positif dan signifikan terhadap nilai tukar karena nilai probabilitas t-statistik $0.0233<0.05\left(\mathrm{H}_{0}\right.$ diterima artinya terdapat hubungan jangka panjang antara variabel inflasi dan nilai tukar rupiah). Sedangkan pada uji jangka pendek inflasi tidak berpengaruh terhadap nilai tukar rupiah, karena nilai probabilitas F-statistik $0.0595>0.05\left(\mathrm{H}_{0}\right.$ ditolak artinya tidak terdapat hubungan jangka pandek antara variabel inflasi dan nilai tukar rupiah) sedangkan pertumbuhan ekonomi berpengaruh terhadap nilai tukar rupiah. Berdasarkan uji jangka panjang menunjukkan bahwa pertumbuhan ekonom memiliki pengaruh yang positif dan signifikan terhadap nilai tukar karena nilai probabilitas t-statistik $0.0000<0.05\left(\mathrm{H}_{0}\right.$ ditolak artinya terdapat hubungan jangka panjang antara variabel pertumbuhan ekonomi dan nilai tukar rupiah). Sedangkan pada uji jangka pendek pertumbuhan ekonomi tidak berpengaruh terhadap nilai tukar rupiah, karena nilai probabilitas F-statistik $0.4989>0.05\left(\mathrm{H}_{0}\right.$ diterima artinya tidak terdapat hubungan jangka pandek antara variabel pertumbuhan ekonomi dan nilai tukar rupiah). Berdasarkan uji model jangka panjang dapat dilihat bahwa nilai probabilitas Fstatistik pada variabel niali tukar kurang dari $0.05(0.000000<0.05)$, dan nilai probabilitas t-statistik $<0.05\left(\mathrm{H}_{0}\right.$ diterima), secara bersama-sama variabel inflasi dan pertumbuhan ekonomi berpengaruh signifikan terhadap variabel nilai tukar. Maka dapat dikatakan bahwa variabel inflasi dan PDB secara bersama-sama berpengaruh signifikan terhadap variabel nilai tukar dalam model jangka panjang. Sedangkan untuk uji jangka pendek tidak ada yang berpengaruh terhadap nilai tukar, karena nilai probabilitas F-statistik $>0.05\left(\mathrm{H}_{0}\right.$ ditolak).

\section{REFERENSI}

Bato, A. R., Taufiq, M., \& Putri, E. R. (2017). Analisis Pengaruh Variabel Makro Ekonomi Terhadap Nilai Tukar Rupiah Tahun 2006-2015. Laa Maisyir: Jurnal Ekonomi Islam, 4(2), 74-95.

Beik, I. S., \& Arsyianti, L. D. (2017). Ekonomi Syariah Pembangunan. Jakarta: PT RajaGrafindo Persada.

Herlambang, P. H. (2019). Implikasi Positivisme terhadap Ilmu dan Penegakan Hukum. Indonesian State Law Review, 2(1), 336-342.

Janie, D. N. A. (2012). Statistik Deskripstif dan Regresi Linier Berganda dengan SPSS. In Statistik Deskripstif dan Regresi Linier Berganda dengan SPSS.

Madura, J. (2006). Keuangan Perusahaan Internasional. Jakarta: Salemba Empat.

Mankiw, N. G. (2007). Makroekonomi (Keenam). Jakarta: Erlangga. 
JoIE: Journal of Islamic Economics | Nur Afriyanti, Luhur Prasetiyo

Muhammad, M. (2014). Kointegrasi dan Estimasi ECM pada Data Time Series. Jurnal Konvergensi, 4(1), 41-51.

Murni, A. (2013). Ekonomika Makro. Bandung: PT Refika Aditama.

Natsir, M. (2014). Ekonomi Moneter dan Kebanksentralan. Jakarta: Mitra Wacana Media.

Puspitaningrum, R., Suhadak, \& Z.A., Z. (2014). Pengaruh Tingkat Inflasi, Tingkat Suku Bunga SBI,dan Pertumbuhan Ekonomi Terhadap Nilai Tukar Rupiah: Studi Pada Bank Indonesia Periode Tahun 2003-2012. Jurnal Administrasi Bisnis, 8(1), 1-9.

Rahardja, P., \& Manurung, M. (2008). Teori Ekonomi Makro: Suatu Pengantar. Jakarta: Lembaga Penerbit Fakultas Ekonomi Universitas Indonesia.

Sudarmiani, Y. W. (2017). Pengaruh tingkat inflasi terhadap nilai tukar rupiah (Studi pada Bank Indonesia periode tahun 2011-2015). EQUILIBRIUM : Jurnal Ilmiah Ekonomi Dan Pembelajarannya, 5(1), 32. https://doi.org/10.25273/equilibrium.v5i1.1004

Sugiyono. (2012). Metode Penelitian Kuantitatif, Kualitatif dan R \& D.Bandung:Alfabeta. In Metode Penelitian Kuantitatif, Kualitatif dan $R \& D$. Bandung: Alfabeta. https://doi.org/10.1017/CBO9781107415324.004

Sugiyono. (2018). Metode Penelitian Kuantitatif. Bandung: Alfabeta.

Sukirno, S. (2004). Makroekonomi Teori Pengantar (Ketiga). Jakarta: PT RajaGrafindo Persada.

Suparmoko. (1994). Pengantar Ekonomika Makro. Yogyakarta: BPFE.

Widarjono, A. (2009). Ekonometrika : Pengantar dan Aplikasinya. Jakarta: Ekonisia. 